\title{
SERVITUDE DI PERBATASAN INDONESIA - MALAYSIA (SEBAGAI ALTERNATIF MENGEMBANGKAN EKONOMI PERBATASAN DI KALBAR- SERAWAK)
}

\author{
Hadi Suratman*, FX. Adji Samekto, Nanik Trihastuti \\ Program Doktor Ilmu Hukum Universitas Diponegoro \\ Jl. Imam Bardjo, S.H. No. 1, Semarang \\ hadisuratman0@gmail.com
}

\begin{abstract}
Cross-border traders are traditional traders from Indonesia who enter Malaysia to trade in the Serikin District, but do not use complete documents either as letters to cross or carry merchandise. Here of course we understand together and why it can happen. Maybe that is where there is dependency between Malaysians and Indonesian traders. This dependence has been beneficial for Indonesian traders. The governments of Malaysia and Indonesia should provide legality for Indonesian traders by conducting Bilateral cooperation between Indonesia and Malaysia regarding a special area of trade using the Servitude Economic Rights. So in this study there are several issues that must be examined namely: 1) Servitude Rights in Border Area Development; 2) Establishment of Cross-Border Trade Zone; 3) Benefits of Special Trade Zone for Indonesia and Malaysia; 4) Efforts to Accelerate Border Economic Growth.
\end{abstract}

Keywords: Servitude Economy; Negative Servitude; Positive Servitude

\begin{abstract}
Abstrak
Pedagang lintas batas adalah pedagang tradisional dari Indonesia yang masuk ke wilayah Malaysia untuk berdagang di Distrik Serikin, namun tidak menggunakan dokumen lengkap baik sebagai surat untuk melintas maupun membawa barang dagangan. Di sini tentunya kita pahami bersama dan mengapa hal itu bisa terjadi. Mungkin di situlah adanya ketergantungan antara Masyarakat Malaysia dengan pedagang Indonesia. Ketergantungan tersebut telah menguntungkan bagi pedagang Indonesia. Pemerintah Malaysia dan Indonesia hendaknya harus memberikan suatu legalitas bagi para pedagang Indonesia dengan melakukan kerja sama Bilateral antara Indonesia dengan Malaysia tentang suatu kawasan khusus dagang dengan menggunakan Hak Ekonomi Servitude. Jadi dalam penelitian ini ada beberapa persoalan yang harus dikaji yaitu: 1) Hak Servitude dalam Pembangunan Kawasan Perbatasan; 2) Pembentukan Kawasan Khusus Dagang Lintas Batas; 3) Manfaat dari Kawasan Khusus Dagang bagi Indonesia dan Malaysia; 4) Upaya Mempercepat Pertumbuhan Ekonomi Perbatasan.
\end{abstract}

Kata Kunci: Ekonomi Servitude; Servitude Negatif; Servitude Positif

\section{A. Pendahuluan}

Setiap negara mempunyai strategi untuk memajukan masyarakatnya secara keseluruhan dalam masalah perekonomian agar lahirnya kesejahteraan . Kesejahtraan tersebut tidak begitu saja hadir tanpa upaya kerja keras dan campur tangan dari negara termasuk Indonesia. Indonesia merupakan
Negara Kesejahteraan sesuai dengan UUD NKRI 1945, hal ini dapat dilihat dari beberapa contoh putusan Mahkamah Konstitusi tidak ada lagi keraguan bahwa Indonesia adalah negara kesejahteraan, putusan Mahkamah diatas berlaku sebagai tafsir konstitusional terhadap sejumlah isu yang berkenaan atau terkait dengan gagasan 
negara kesejahteraan menurut UUD NKRI 1945 yang dipraktikan di Indonesia (Palaguna, 2019:19).

Negara kesejahteraan di suatu negara mempunyai banyak perbedaan antara negara dengan sistem pemerintahan yang berbeda, namun tujuannya adalah menciptakan kemajuan perekonomian rakyatnya sehingga menjadi sejahtera. Menurut Paul Spicker, negara kesejahtraan tiada lain adalah bentuk - bentuk kelembagaan dan perlindungan sosial. Negara kesejahteraan dibanyak negara modern saat ini dalam bentuk polapola perlindungan sosial yang sebelumnya telah dikembangkan melalui tindakan sosial Kolektif. Sehingga membangun negara kesejahteraan menjadi obsesi banyak negara baru terutama di Asia yang merdeka setelah Perang Dunia II. Beberapa negara seperti Korea Selatan, Taiwan, dan Singapura, telah cukup berhasil membangun negara kesejahteraannya (Triwibowo, 2006:6). Demikian pula, negara Kesatuan Republik Indonesia, sebagaimana diamanatkan dalam Undang-Undang Dasar Negara Kesatuan Republik Indonesia 1945.(Sukmana, 2016)

Negara Indonesia merupakan negara yang cukup luas, persebaran masyarakatnya tidak merata, sehingga pertumbuhan perekonomian antara masyarakat diwilayah satu berbeda dengan masyarakat diwilayah lainnya. Kalimantan Barat merupakan wilayah yang langsung berbatasan dengan negara Malaysia sehingga terdapat suatu keunikan tersendiri dalam melakukan kegiatan ekonomi. Kegiatan ekonomi tersebut adalah suatu bentuk dagang lintas batas oleh masyarakat Indonesia, namun kawasan yang dipergunakan untuk berdagang adalah kawasan Pasar Serikin yang masuk dalam yurisdiksi negara Malaysia tanpa adanya kesepakatan bilateral.

Hadirnya Pasar Serikin bukan karena suatu perjanjian bilateral antara Indonesia dan Malaysia, sebagaimana diatur dalam Border Crossing Agreement (BCA), ataupun dalam Border Trade Agreement (BTA). Pasar Serikin merupakan wilayah yang digunakan untuk berdagang bagi orang- orang Indonesia yang telah ada jauh sebelum diberlakukannya Border Trade Agreement (BTA) itu sendiri, sedangkan Border Trade Agreement mulai diberlakukan tahun 1970. Perubahan Border Trade Agreement (BTA) Tahun 1970 mengatur beberapa hal prinsip: yaitu (1) pengertian perdagangan lintas batas, (2) pelaku lintas batas serta (3) jenis dan nilai barang/produk. Pelaku lintas batas adalah orang (penduduk) yang berdiam (bertempat tinggal) di dalam kawasan perbatasan kedua negara, dan memiliki paspor yang dikeluarkan masing-masing negara maupun pas lintas batas yang dikeluarkan berdasarkan ketentuan Border Crossing Agreement (BCA), yang terakhir adalah BCA Tahun 2006, sedangkan saat disepakatinya BTA Tahun 1970 rujukannya adalah BCA Tahun 1967. Perdagangan lintas batas dapat berbentuk perdagangan lintas batas darat, yaitu perdagangan yang dilakukan melalui daratan antar kawasan perbatasan darat kedua negara; dan perdagangan lintas batas laut, yang diartikan sebagai perdagangan yang dilakukan melalui kawasan perbatasan laut dari kedua negara. BTA ditandatangani di Jakarta pada tanggal 24 Agustus 1970 (Sosrosoediro, 2018).

Perbatasan menurut Undang-Undang No 43 Tahun 2008 tentang wilayah negara pada Pasal 1 (6) berbunyi: Kawasan Perbatasan adalah bagian dari wilayah negara yang terletak pada sisi dalam sepanjang batas wilayah Indonesia dengan negara lain, dalam hal Batas Wilayah Negara di darat, Kawasan Perbatasan berada di kecamatan. Pada umumnya wilayah pebatasan sering menimbulkan konflik baik masalah tapal batas, ataupun masalah lainnya sehingga dapat mengakibatkan hubungan yang kurang harmonis. Untuk menghindari konflik di wilayah perbatasan tentunya perlu dilakukan kerjasama bilateral yang tujuannya adalah untuk kemajuan bagi masyarakat kedua negara, khususnya masyarakat di perbatasan.

Untuk melakukan kerja sama antara satu negara dengan negara lainnya, tentulah terlebih dahulu adanya suatu hubungan baik yang dilakukan secara individu, kelompok 
masyarakat, melalui organisasi, kelompok atau negara-negara dengan negara. Negaranegara merdeka satu sama lain, paling tidak secara hukum mereka memiliki kedaulatan, akan tetapi hal itu tidak berarti mereka terasing atau terpisah satu sama lain. Sebaliknya, mereka berdekatan dan saling mempengaruhi dan oleh karena itu tidak ada jalan lain kecuali harus mendapatkan cara untuk hidup berdampingan dan berhadapan satu sama lain. Mereka biasa berhubungan dalam pasar internasional yang mempengaruhi kebijakan pemerintahannya dan kekayaan serta kesejahteraan warga negaranya. Hal itu menunjukan bahwa mereka berhubungan satu sama lain (Jacson, $\mathrm{R}$ dan Serensen, 2014).

Serikin adalah suatu distrik yang berada di negara Malaysi. Kawasan Serikin telah dijadikan wilayah dagang bagi masyarakat Indonesia. Pasar Serikin tidak lahir dari perjanjian bilateral antara Indonesia Malaysia seperti Border Crossing Agrement (BCA) dan Border Trade Agrement (BTA) ("Perdagangan Lintas Batas di Kawasan Perbatasan Indonesia - Malaysia: Sebuah Kajian Terhadap Implementasi Border Trade Agreement (BTA) Tahun 1970 di Kalimantan Timur," 2013). Atas dasar tersebut maka perlu dilakukan perjanjian bilateral khusus mengatur area yang dijadikan tempat berdagang. Atas dasar itu perlu dibuat perjanjian Border Area Agreement (BAA). Dengan adanya perjanjian BAA tadi, bisa didalamnya ditambah dengan Klausula berkaitan peraturan khusus tentang wilayah perdagangan Lintas batas.

Pengaturan khusus yang dimaksud oleh penulis, bisa berkaitan dengan pengaturan khusus tentang bea masuk, pajak, jenis barang yang dibawa, serta persyaratan lainnya yang berkaitan dengan perdagangan. Kekhususan tersebut nantinya merupakan sesuatu kesepakatan yang mempermudah para pedagang lintas batas. Hal ini perlu dilakukan, karena pasar Serikin merupakan pasar tradisional yang berada di wilayah Malaysia yang sipatnya menetap, sehingga perlu perjanjian bilateral tambahan, mengingat perjanjian $\mathrm{BCA}$ dan BTA tidak mengatur hal tersebut.

Pasar Serikin, atau yang dikenal dengan sebutan Pasar " Bandung", ataupun dapat disebut sebagai Pasar Borong dapat disamakan dengan wilayah ekonomi dengan Hak servitude, Servitude (servitut). Servitude muncul manakala wilayah suatu negara terdapat hak-hak (legal rights) negara lain. Negara yang menikmati servitude berhak untuk melakukan suatu perbuatan di wilayah negara lain. Misalnya saja suatu negara mempunyai hak melewat di dalam suatu negara lain (Adolf, 2002).

Wilayah ekonomi servitude menurut hukum Internasional adalah wilayah negara lain yang dapat dipergunakan oleh suatu negara untuk kepentingan ekonominya dengan melalui perjanjian bilateral. Hadirnya Pasar Serikin tidak melalui perjanjian bilateral, dan juga bukan wilayah dengan hak servitude untuk Indonesia, namun secara defacto wilayah tersebut sudah seperti wilayah Indonesia, atau wilayah servitude yang diperuntukan bagi Indonesia.

Negara Indonesia dan Malaysia seharusnya mempunyai kebijakan yang sama dalam melihat permasalahan diperbatasan. Kebijakan yang sama tadi bisa berupa regulasi Hukum yang bersifat khusus, misalnya dengan perjanjian bilateral seperti yang pernah dilakukan sebagaimana yang pernah disepakati yaitu Border Crossing Agrement (BCA) dan Border Trade Agreement (BTA). Perjanjian kerja sama yang penulis maksud adalah perjanjian yang tidak hanya menyangkut masalah BCA tentang lintas batas atau BTA yang mengatur tentang jumlah barang yang dibawa melintasi perbatasan, namun agreement yang harus dibuat oleh kedua negara adalah agreement khusus berkaitan dengan suatu kawasan bersama yang digunakan sebagai wilayah dagang.

Indonesia telah membuat peraturan yang berkaitan dengan masalah perbatasan, yaitu melalui Perpres Nomor 12 Tahun 2011 dalam Pasal 4 (d) mengatur "Inventarisasi potensi sumber daya dan 
rekomendasi penetapan zona pengembangan ekonomi, pertahanan, sosial budaya, lingkungan hidup dan zona lainnya di kawasan perbatasan". Dengan dikeluarkan Perpres tersebut memang belum secara khusus mengatur mengenai aktivitas di perbatasan. Selanjutnya Pemerintah Indonesia disamping memberlakukan ketentuan Perpres di atas, juga mengeluarkan peraturan Presiden No 31 Tahun 2015 tentang Rencana Tata Ruang Kawasan Perbatasan Negara di Kalimantan sebagai mana pada Pasal 1 (35) "Gubernur adalah Gubernur Kalimantan Barat, Gubernur Provinsi Kalimantan Timur, dan/atau Gubernur Provinsi Kalimantan Utara”, Pasal 2 (36) "Bupati adalah Bupati Sambas, Bupati Bengkayang, Bupati Sanggau, Bupati Sintang, Bupati Kapuas Hulu, Bupati Mahakam Ulu, Bupati Malinau, dan Bupati Nunukan". Peraturan tentang Perbatasan Indonesia dengan Malaysia, diatur juga dalam Perda Provinsi Kalimantan Barat Tentang Rencana Tata Ruang Wilayah Provinsi Kalimantan Barat Tahun 2014 dalam Pasal 1 (35) "Kawasan Perbatasan adalah wilayah kebupaten/Kota yang secara geografis dan demografis berbantasan langsung dengan negara tetangga dan/atau laut lepas". Dengan adanya Perpres dan Perda yang khusus mengatur wilayah perbatasan Kalimantan tidak secara nyata, tetapi selalu difokuskan pada masalah kedaulatan negara sebagaimana diatur pada Peraturan Presiden No. 31 Tahun 2015 tentang Rencana Tata Ruang Kawasan Perbatasan Negara di Kalimantan Pasal 6 "Penataan ruang kawasan perbatasan negara bertujuan untuk mewujudkan keutuhan wilayah negara di perbatasan dengan menegakkan kedaulatan negara dan menjaga pertahanan negara pada kawasan perbatasan negara."

\section{B. Pembahasan}

\section{Hak Servitude dalam Pembangunan Kawasan Perbatasan}

Dalam Hukum Internasional dikenal hak servitude, dimana hak tersebut sering dilakukan pada negara-negara eropa. Hak servitude adalah hak suatu negara demi kemajuan ekonominya, dapat membangun fasilitasnya di negara lain, misalnya Perancis demi meningkatkan transportasi di bidang angkutan perkeretaapian, maka menjadikan wilayah Inggris dipakai untuk pembangunan rel kereta api, dan Inggrispun menyetujui. Begitu juga bagi negara di daerah Amerika, dimana di negara-negara tersebut hampir dikatakan pasti ada jalan kereta api yang menghubungkan dari suatu negara ke negara lainnya. Suatu hal yang cukup penting berkaitan dengan kedaulatan negara adalah Servitude. Servitude menurut F.A.Vali yaitu a condition in which one lacks liberty especially to determine one's couremof action or way of life (F.A.Vali, 1958) (suatu kondisi dimana seseorang kurang memiliki kebebasan, terutama untuk menentukan tindakan atau cara hidup). Servitude muncul manakala wilayah suatu negara terdapat hak-hak (legal right) negara lain. Negara yang menikmati servitude berhak untuk melakukan suatu perbuatan di wilayah negara lain. Misalnya saja suatu negara mempunyai hak melewat didalam suatu negara lain (Adolf, 2002:159-160). Sebaliknya, negara-negara yang mempunyai beban untuk memberikan servitude ini kepada suatu negara berkewajiban untuk tidak melakukan perbuatan yang menghalangi hak-hak negara lain. Misalnya saja membangun pangkalan militer yang melekat servitude diatasnya sehingga negara yang menikmati servitude menjadi terhalang. Dari pengertian tersebut bahwa servitude merupakan pembatasan terhadap kedaulatan (teritorial) negara (Adolf, 2002:159-160).

Bagi Indonesia dan Malaysia tentunya harus juga berpikir tentang hak servitude sebagai suatu upaya untuk memajukan masyarakat perbatasan kedua negara melalui kerjasama bilateral. Indeonesia dengan Malaysia pernah membuat perjanjian bilateral, kerjasama tersebut berkaitan dengan Sosek Malindo yang merupakan kerja sama dalam bidang sosial dan ekonomi, tetapi kerjasama tersebut hanya 
bersifat pemahaman, sebagai contoh Malaysia menginginkan suatu aturan yang sama dengan negaranya, misalnya berkaitan dengan masalah kendaraan asing yang berada di daerahnya hanya boleh 90 hari, dan begitu juga Indonesia. Jadi ini sebenarnya bukan suatu kesepakatan melainkan hanya merupakan persamaan.

Perkembangan pada Sosek Malindo lebih cenderung diutamakan kepada kemampuan wilayah masing-masing. Hal ini tentunya dapat dilihat dari cara kerja Sosek Malindo tersebut, misalnya Sosek Malindo dibagi atas dua bentuk, satu Sosek khusus Indonesia, sedangkan lainnya adalah Sosek khusus Malaysia. Jika kita pahami sebenarnya bukan merupakan suatu bentuk kerjasama tetapi hanya penyesuaian.

Masalah perbatasan memang memerlukan perhatian tersendiri, karena masalah perbatasan sangat kompleks, dan untuk mengembangkan perbatasan harus mempunyai konsep yang khusus, misal daerah mana yang berada di wilayah perbatasan kedua negara, yang bisa dibangun suatu fasilitas, dan juga siapa yang akan membangun rencana kerja hendaknya harus diatur dengan baik.

Hak servitude menjadi kebiasaan internasional, dan kemudian telah menjadi bagian dari hukum internasional. Hal demikian muncul karena di wilayah suatu negara terdapat hak-hak (legal right) negara lain. Setiap negara yang memiliki Hukum Sipil (Civil Law), maka mengenal hak servitude. Di dalam Hukum Sipil Indonesia diatur di dalam Burgerlijk Wetboek yang terdapat pada Pasal 674 yang berbunyi "Pengabdian pekarangan adalah suatu beban yang yang diberikan kepada perkarangan milik orang yang satu, untuk digunakan oleh dan demi kebahagiaan pekarangan milik orang yang lain".

Dari bunyi pasal tersebut jelas jauh sebelum Indonesia merdeka, hak servitude telah berlaku di Hindia Belanda. Hukum Belanda yang diadopsi ke dalam hukum Indonesia memang tidak tegas mengartikan bahwa perkarangan termasuk teritorial negara lain. Tetapi yang jelas bahwa hak servitude adalah kebiasaan internasional yang kemudian dikodifikasikan kedalam hukum positip. Hak Servitude di dalam ketentunan hukum Indonesia dapat ditafsirkan secara analogi yang meluas, yaitu perkarangan dapat disamakan wilayah, sedangkan wilayah tadi mempunyai pengertian menyempit menjadi perkarangan.

Negara yang menikmati servitude berhak untuk melakukan suatu perbuatan hukum divvilayah negara lain. Di perbatasan Kalimantan Barat belum ada yang namanya hak servitude, dan bahkan semua pembangunan baik itu pembangunan kebun yang terdapat di Desa Sebunga dilakukan dengan cara sembunyi-sembunyi, begitu juga dalam pengusahaan hutan dan sebagainya.

Hak servitude pada dasamya merupakan kebiasaan internasional oleh suatu negara terhadap negara lain. Hak servitude lahir karena adanya kepentingan nasional suatu negara, baik kepentingan yang berkaitan dengan hukum, politik, militer ataupun ekonomi. Hak servitude demi kepentingan ekonomi banyak diterapkan oleh negaranegara yang kebutuhan ekonominya ada di negara lain, ataupun sebaliknya. Menurut Oppenhein "Servitude ekonomi (Economic Servitudes) merupakan hak untuk tujuan atau kepentingan perniagaan, lalu lintas perdagangan, dan hak- hak ekonomi lainnya, hak untuk menikmati pembebasan bea cukai. Di wilayah atau zona ekonomi tertentu, atau untuk berlayar, dan membangun fasilitas transportasi di negara lain" (Adolf, 2002).

Di perbatasan Kalimantan Barat dengan Serawak, memerlukan hak servitude ekonomi. Kepentingan ekonomi perbatasan tentunya harus dilihat dengan lebih rasional, misalnya di negara manapun wilayah perbatasan harus dibangun sarana ekonomi yang sifatnya mempermudah untuk melakukan interaksi, ataupun transaksi. Kemudahan tersebut, dapat berupa lintas batas kedua negara, yang kemudian tidak hanya difasilitasi oleh Pos Lintas Batas (PLB), namun dikembangkan menjadi Pos Pemeriksaan Lintas batas (PPLB). Kemudahan tersebut masih dapat 
dikembangkan lagi menyangkut bea masuk dan cukai bagi kedua negara.

Wilayah perbatasan kedua negara yang terletak di sepanjang Kalbar dengan Serawak tentunya tidak hanya atas dasar kemudahan yang sifatnya sepihak, namun harus dipikirkan perimbangan yang nyata. Wilayah Sempadan Malaysia telah dibangun fasilitas transportasi, sehingga menjadi kemudahan dalam mengawasi perbatasan di kawasan Serawak yang mobilitasnya cepat. Sementara bagi Indonesia, perbatasan Sempadan tidak memiliki transportasi yang memadai, melainkan hutan belantara yang menjadi permasalahan hingga sekarang.

Perlu dikembangkannya hak servitude oleh kedua negara, ataupun oleh pihak Malaysia harus memjadi pemikiran bersama. Jika dilihat berdasarkan perkembangan perekonomian Indonesia, memang sulit untuk membangun wilayah perbatasan pada saat sekarang. Pengamanan perbatasan perlu dilakukan, di samping itu sasaran dari pengamanan tersebut adalah untuk kepentingan kedua negara. Perbatasan yang tidak kondusif tentunya mengkhawatirkan bagi kedua negara, kejahatan terorganisir berkembang dan bahkan sulit untuk diberantas. Pemerintah Indonesia hendaknya perlu melakukan kerjasama dengan Malaysia untuk memanfaatkan hak servitude di wilayah perbatasan.

Hak servitude dapat dilakukan oleh pemerintah Indonesia di Malaysia, misalnya Indonesia berkeinginan membangun fasilitas ekonomi di negara Malaysia. Pemikiran tersebut tentunya upaya yang baik, namun tentunya berkaitan dengan biaya besar yang harus dikeluarkan.

Pemerintah sebenarnya berpikir pada saat itu untuk membangun transportasi lintas utara yang pemah dicanangkan, namun karena beberapa pertimbangan maka upaya tersebut tidak tercapai. Timbul suatu pemikiran apa yang menyebabkan tidak terlaksananya usaha tersebut, yang jelas pemerintah memang kurang tertarik pada masalah perbatasan, atau memang jika masalah pembangunan lintas utara terlaksana, mungkin ada kesulitan bagi para oknum dari pemerintah, ataupun para sindikat untuk melakukan pencurian kayu.

Hak servitude bisa dimanfaatkan dengan jalan kerjasama, tentunya ada kompensasi bagi pihak yang mempunyai hak servitudes di Indonesia. Seperti kasus The Free Zone Of Savoy And District Of Gex dimana Permanent Court of intemasional Justice mengharuskan Perancis untuk melaksanakan suatu janji yang dibuat, oleh negara-negara Sardinia, dimana Perancis diberi suatu wilayah untuk melakukan aktifitasnya dinegara tersebut, namun harus bebas dari cukai (Alxehurst, 1984).

Jika wilayah perbatasan sangat bermamfaat bagi Malaysia, tentunya pemerintah Indonesia harus melakukan suatu tindakan, yaitu dengan mempertimbangkan dari segala aspek, disamping itu pemerintah Indonesia harus berlapang dada jika wilayahnya dibangun fasilitas oleh Malaysia. Cara membangun fasilitas di negara Indonesia tentunya bukan merupakan suatu tindakan yang mengurangi yurisdiksi Indonesia, ataupun telah menjual teritorial, namun keuntungan bagi Indonesia justru dapat melakukan pengembangan ekonomi, disamping itu ada keuntungan lain yaitu berkurangnya upaya untuk terjadinya pencurian kayu, dan juga pengawasan terhadap perbatasan akan lebih mudah.

Digunakannya hak servitude tentulah menimbulkan kompensasi, dan kompensasi dapat dibicarakan, ataupun dengan perjanjian, misalnya kita dapat meminjamkan wilayah perbatasan untuk membuat jalan, perkebunan, ataupun fasilitas lainnya. Jika hak servitude dilaksanakan, maka Indonesia dapat menyediakan sumber alamnya, ataupun dapat menyediakan tenaga kerja baik di sektor perkebunan ataupun industri perkayuan. Dengan demikian masyarakat perbatasan akan terbantu.

Hak servitude bagi negara Malaysia tidak hanya menguntungkan bagi Malaysia, namun menguntukan bagi Indonesia, keuntungan tersebut tentunya akan berpengaruh terhadap perekonomian di 
perbatasan, terhadap kehidupan sosial masyarakat perbatasan, dan bahkan bermanfaat terhadap keamanan negara. Hak servitude juga dapat berguna uintuk mencegah kejahatan terorganisir, ataupun kejahatan internasional lainnya.

Wilayah perbatasan yang telah disepakati sebagai daerah servitude, tentunya akan menambah pemasukan bagi Indonesia. Pemerintah Indonesia dapat memanfaatkan dana tersebut untuk membangun daerah lainnya yang berada di daerah perbatasan lainnya. Jangka waktu hak servitude dapat ditentukan dalam suatu perjanjian dan dapat diperpanjang atas kesepakatan yang tentunya sesuai dengan hukum internasional.

\section{Kawasan Khusus Dagang Lintas Batas}

Kawasan Khusus Dagang Lintas Batas (KKDLB) atau Special Area of Border Cross yang dimaksud dalam tulisan ini adalah suatu kawasan yang dibentuk untuk aktivitas perdagangan di perbatasan antara Indonesia dan Malaysia, yang pengaturannya dalam bentuk perjanjian kerja sama bilateral antara Indonesia dan Malaysia.

Kawasan perbatasan memerlukan adanya suatu kegiatan ekonomi yang bisa memacu perkembangan di wilayah tersebut. Melihat potensi ekonomi di perbatasan, pemerintah belum membangun suatu zona perdagangan antarpenduduk di wilayah perbatasan, di mana penduduk perbatasan dari dua negara dapat melakukan aktivitas ekonomi dan perdagangan sebagaimana layaknya interaksi yang biasa dilakukan oleh penduduk di pasar tradisional tanpa perlu dibatasi oleh peraturan kenegaraan yang malah membuat aktivitas ekonomi dan perdagangan menjadi mandek. Tentunya akan ada permasalahan ikutan, baik yang bersifat kriminal atau lainnya, namun itu harus bisa diantisipasi dan dikendalikan. Dua negara bertetangga seharusnya dapat bekerja sama menetapkan suatu area perdagangan yang berada di antara pos penjagaan perbatasan dan peraturan mengenai zona perdagangan antarpenduduk dan sekaligus mengelolanya bersama-sama. Dengan demikian keberadaan zona perdagangan antar-penduduk tersebut dapat menjadi penggerak perkembangan ekonomi kabupaten/kota yang berada di wilayah perbatasan (Wangke, 2013).

Perdagangan lintas batas yang terjadi saat ini adalah para pedagang asongan yang masuk ke wilayah Sarawak membawa barang dagangan dan menjualnya di suatu tempat, sehingga terbentuklah pasar tradisional/'pasar kaget' di wilayah Serikin (Sarawak). Para pedagang tersebut tidak hanya berasal dari Kabupaten Bengkayang saja melainkan dari luar Bengkayang juga, misalnya pedagang asal Kabupaten Sambas, pedagang asal Kota Singkawang, Pontianak, bahkan ada pula dari Pulau Jawa. Jenis barang yang diperdagangkan di Pasar Kaget Serikin seperti ikan segar, sayur mayur, rempah-rempah, buah-buahan, pakaian jadi, barang-barang dari kulit, keramik hias, barang-barang kerajinan dari anyaman rotan, mainan anak-anak, rokok kretek, mie instan, dan makanan tradisional, serta aksesoris. Aktivitas 'pasar kaget' ini hanya berlangsung selama dua hari dalam seminggu, yaitu pada hari Sabtu dan hari Minggu (Suwartiningsih, S ; Samiyono, D and Purnomo, 2018).

Pasar Serikin begitu berkembang sehingga menjadi tumpuan masyarakat perbatasan, dengan demikian maka pemerintah kedua negara harus mampu membuat kebijakan yang berkaitan dengan pengembangan perekonomian bagi masyarakat perbatasan di kedua negara bagi masyarakat kecil yang tidak mampu bersaing dengan para pedagang besar yang mempunyai kelebihan dalam semua hal termasuk melakukan eksport-import sehingga terjadi monopoli. Menurut Richard A. Posner membahas kebijakan pengaturan, anti monopoli atau aturan anti-trust, pasar non-kompetitif - monopoli alami atau oligopoli, dan efisiensi aturan hukum dan prosedur administrasi yang dapat digunakan untuk mengendalikan mereka (Medema, 1998:213). 


\section{Manfaat dari Kawasan Khusus Dagang bagi Indonesia dan Malaysia}

Kawasan Khusus Dagang Lintas Batas (KKDLB), harus dapat dijadikan suatu kawasan dagang tradisional yang bermanfaat bagi kedua negara. Kemanfaatan dari pasar tradisional di wilayah Malaysia tepatnya di distrik Serikin merupakan pasar yang harus dikembangkan oleh kedua negara, hal ini dikarenakan kawasan Serikin merupakan perdagangan tradisional, namun sudah menjadi pasar internasional. Dikatakan sebagai pasar internasional, karena dilihat dari wilayahnya, yaitu melibatkan dua negara Indonesia dan Malysia. Sedangkan dari para pembeli tidak hanya dari sekitar masyarakat Kuching, namun banyak berdatangan dari negara bagian lainnya, seperti masyarakat dari negara bagian Sabah, dari Semenanjung, dan bahkan dari negara Brunei Darussalam.

Banyaknya pembeli atau yang berbelanja, tidak lain dikarenakan adanya daya tarik tersendiri. Daya tarik terebut adalah, bahwa Pasar Serikin dijadikan tempat wisata masyarakat Malaysia. Daya tarik inilah oleh pemerintah Malaysia kawasan Serikin dijadikan salah satu destinasi wisata di Malaysia. Dengan demikian dari keberadaan Pasar Serikin maka kedua negara mendapat keuntungan. Keuntungan tersebut adalah masyarakat Indonesia dapat meningkatkan kebutuhan Ekonominya, dan produk Indonesia menjadi unggulan di Malaysia. Sedangkan bagi masyarakat Malaysia keuntungan yang didapat adalah terpenuhinya kebutuhan masyarakat perbatasan Malaysia dan negara bagian lainnya. Keuntungan lainnya bagi pihak Malaysia dalam hal ini Kuching menjadi tempat wisata karena adanya pasar Serikin yang dikenal dengan sebutan "Pasar Bandung".

\section{Mempercepat Ekonomi Perbatasan \\ Pertumbuhan}

Pasar Serikin secara tidak langsung memberikan keuntungan tersendiri dari pedagangan Internasional yang dilakukan oleh Pemerintah Kalimantan Barat, hal ini dikarenakan perdagangan yang dilakukan oleh masyarakat perbatasan di Pasar Serikin sungguh menguntungkan, namun jika melalui ekspor melalui PLBN barang yang masuk ke Malaysia tidak menguntungkan bagi Indonesia khususnya Kalimantan Barat. Hal ini dikarenakan impor yang dilakukan Malaysia lebih tinggi.

Di perbatasan terdapat beberapa pintu masuk ke Malaysia, namun barang yang masuk dari Indonesia ke negara Malaysia yang dapat diperdagangkan langsung adalah yang melalui PLB Jagoi Babang, sedangkan dari PLB dan PLBN lainnya dilakukan oleh eksportir dan importir besar saja, dengan demikian tidak menjamah masyarakat perbatasan.

Sebagai wilayah terdepan negara, pengembangan kawasan perbatasan mendapatkan perhatian khusus oleh dari pemerintah pusat maupun pemerintah daerah. Ini karena wilayah perbatasan juga merupakan salah satu kawasan strategis, yaitu kawasan yang secara nasional menyangkut hajat hidup orang banyak, ditinjau dari sudut kepentingan politik, ekonomi, sosial, budaya, lingkungan maupun pertahanan keamanan. Cara pandang kawasan perbatasan yang dulunya berorientasi 'inward looking' menjadi 'outward looking' sebagai pintu gerbang aktivitas ekonomi dan perdagangan dengan negara tetangga (Purnamasari, 2016).

Indonesia merupakan negara berdaulat yang mempunyai yurisdiksi masing-masing sehingga keberadaan Pasar Serikin jika dikaji secara hukum masuk dalam jurisdiksi Malaisia, dengan demikian dapat dikatakan bahwa pedagang perbatasan asal Indonesia telah melakukan lintas batas serta melakukan dagang di Malaysia tidak sesuai dengan ketentuan yang berlaku dan telah terjadi pelanggaran atas jurisdiksi negara Malaysia. Jurisdiksi adalah kekuasaan atau kewenangan hukum negara terhadap orang, benda atau peristiwa (hukum). Pada prinsipnya negara memiliki kekuasaan untuk mengatur hubungan hukum yang dilakukan oleh orang (warga negara atau warga negara 
asing) yang berada di wilayahnya. Negarapun memiliki wewenang yang sama untuk mengatur benda-benda, atau peristiwa-peristiwa (hukum) yang terjadi dalam wilayahnya (Adolf, 2002:183).

\section{Simpulan}

Dengan adanya kerjasama bilateral antara Indonesia dengan Malaysia, penyelesaian masalah perbatasan bukanlah hal yang sangat mustahil. Malaysia dan Indonesia harus membuat perjanjian bilateral yang tidak hanya sebagaimana dimaksud dalam BCA dan BDA, namun kedua negara harus membuat suatu perjanjian yang berkaitan dengan suatu wilayah ekonomi dengan hak servitude yaitu Borde Area Agreement (BAA) sebagai pelengkap dari BCA yang hanya mengatur pelintas batas, serta BTA, yang hanya mengatur tentang perdagangan di perbatasan.

Adanya perjanjian yang berkaitan dengan suatu area dagang dapat mempercepat pertumbuhan perekonomian masyarakat perbatasan, hal ini dapat dilihat dari majunya Pasar Serikin sebagai suatu kawasan dagang bagi orang Indonesia, dengan demikian seharusnya pemerintah Indonesia dan Malaysia menjadi kawasan Serikin sebagai ekonomi servitude bagi Indonesia di Malaysia.

\section{DAFTAR PUSTAKA}

Adolf, H. (2002). Aspek-aspek Negara dalam Hukum Internasional. Raja Grafindo Persada.

Alxehurst, M. (1984). Modern Intoduction to International Law (5th ed.). George Allen and Unwin.

F.A.Vali. (1958). Servitudes Of Internasional Law “ A Study Of Rights In Foreign Territory” (2nd ed.). Stevens \& Sons Limitded.

Jacson, R dan Serensen, G. (2014). Pengantar Hubungan Internasional: Teori dan Pendekatan. Pustaka Pelajar.
Medema, S. (1998). Wandering the Road from Pluralism to Posner: The Transformation of Law and Economics, 1920s-1970s. In. In The Transformation of American Economics: From Interwar Plural-ism to Postwar Neoclassicism History of Political Economy Annual Supplement 30 (p. 213). Duke University Press.

Palaguna, I. D. G. (2019). Wefare State vs Globalisasi (Gagasan Negara Kesejahtraan Indonesia). Raja Grafindo Persada.

Perdagangan Lintas Batas di Kawasan Perbatasan Indonesia - Malaysia; Sebuah Kajian Terhadap Implementasi Border Trade Agreement (BTA) Tahun 1970 di Kalimantan Timur. (2013). Kabar Perbatasan Kaltim.

Purnamasari, W. . . [et. al. (2016). Perkembangan Pembangunan Ekonomi Kawasan Perbatasan Negara Indonesia Malaysia di Sambas. Jurnal Diskursus Islam, 4(2), 217.

Sosrosoediro, E. R. (2018). Border Trade Agreement dan Integrasi Ekonomi di Perbatasan (Kajian Kebijakan Perdagangan Lokal di Perbatasan Indonesia dan Malaysia di SebatikNunukan Kalimantan Utara). Conference of the Parties to the Basel Convention on the Control of Transboundary Movements of Hazardous Wastes and Their Disposal 60 Tahun Antropologi Indonesia, 2.

Sukmana, O. (2016). Konsep dan Desain Negara Kesejahteraan (Welfare State). Jurnal Sospol, 2(1).

Suwartiningsih, S; Samiyono, D and Purnomo, D. (2018). Harmonisasi Sosial Masyarakat Perbatasan Indonesia Malaysia. Jurnal Hubungan Internasional, 7(1), 4.

Triwibowo, D. dan S. B. (2006). Mimpi Negara Kesejahteraan. LP3ES. 
Wangke, H. (2013). Perdagangan Lintas

Batas Antar-Negara: Memacu

Pembangunan Ekonomi Kabupaten

Bengkayang Dan Kabupaten Belu.

Jurnal Politica, 4(1), 4. 